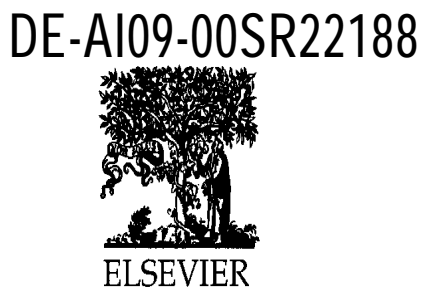

\title{
The use of tree shelters in restoring forest species to a floodplain delta:5-year results
}

\author{
William H. Conner ${ }^{a, *}$, L. Wayne Inabinettea Evaden F. Brantley ${ }^{b}$ \\ Baruch Forest Science Institute, P.O. Box 596, Georgetown, SC 29442, USA \\ ${ }^{b}$ Weeks Bay Watershed Project, 11300 US Highway 98, Fairhope, AL 36532, USA \\ Received 19 March 1999; received in revised form 16 April 1999; accepted 7 September 1999
}

\begin{abstract}
Without herbivory control, natural seed sources, and seasonal flood events, recovery of the Pen branch delta in South Carolina to former conditions (prior to thermal discharge) may take many years. To assess the recovery process, seedlings of baldcypress (Tuxodium distichum), water tupelo(Nyssa aquatica), swamp blackgum (Nyssa sylvaticu var. biflora), and green ash (Fraxinus pennsyluanica) we re planted in four areas of the delta in 1994. One-half of the seedlings were protected using tree shelters $1.5 \mathrm{~m}$ tall. Heights of seedlings were taken after planting and at the end of each growing season from 1994 to 1998. Survival at the end of 5 years ranged from 67 to $100 \%$ for seedlings in tree shelters and 2-90\% for those not in tree shelters. Survival of seedlings without tree shelters was generally low, and mortality was attributed mainly to beaver damage. Although water tupelo, swamp blackgum, and green ash seedlings tended to die once clipped by beaver, $85 \%$ of the clipped baldcypress resprouted after clipping, and new sprouts grew vigorously. During year 1, height growth of tree shelter seedlings was significantly greater than non-tree shelter seedlings for ail species, but once the seedling emerged from the top of the shelter, growth differences declined dramatically. Differences in height growth among areas was highly variable from year to year, and no one species tended to grow better in one are a over another throughout the period. Restoration of the Pen branch delta to a baldcypress-water tupelo forest similar to the surrounding forest is possible. Baldcypress and water tupelo seem ideally suited to growing in all areas of the delta equally well, but it may take 10-20 years before the seedlings are of sufficient size to not be affected by herbivory and old enough to produce sufficient quantities of seed to maintain the forest. 2000 Elsevier Science B.V. All rights reserved.
\end{abstract}

Keywords: Restoration; Forested wetlandșree shelters; Herbivory; Pen branch; Savannah river

\footnotetext{
* Corresponding author. Tel.: + 1-843-5466323; fax: 1+ 843-5466296.

E-mail address:wconner@clemson.edu (W.H. Conner).
}

\section{Introduction}

The original swamp forest within Pen branch delta consisted of a closed canopy forest dominated by baldcypress (Taxodium distichum [L.] Rich.) and water tupelo (Nyssa aquatica L.) 
(Sharitz et al., 1974a). Thermal effluents from nuclear production reactors were released directly into Pen branch from 1954 to 1988 (Sharitz et al., 1990). High water temperatures $\left(40-50^{\circ} \mathrm{C}\right) \mathrm{com}$ bined with increased water flows $\left(0.3-11 \mathrm{~m}^{3} / \mathrm{s}\right)$, increased siltation rates $(>0.5 \mathrm{~m}$ deposited in places), and man-made flooding events asynchronous with natural events were considered to be responsible for the death of most of the existing vegetation on the delta (Sharitz et al., 1974a; Wike et al., 1994). Studies of the effects of high temperature flooding on baldcypress, water tupelo, black willow (Salix nigra L.), and buttonbush (Cephalanthus occidentalis L.) showed a reduction in survival rates, lower biomass and productivity rates, and altered physiological responses for some of the species (Scott et al., 1985; McLeod et al., 1987; Donovan et al., 1988).

Alteration of natural hydrologic cycles is an important factor in the mortality of trees in floodplain areas. Flooding usually occurs in the dormant season which minimizes damage sustained by plants in waterlogged soils (Sharitz and Mitsch, 1993). A change in the seasonal flooding cycle may lower community productivity and kill certain tree species only adapted to dormant season flooding. At present, the delta is constantly flooded (Kolka et al., 1998). Although water tupelo and baldcypress are flood tolerant, abnormally high water levels for several growing seasons may result in stunted growth and eventually death (Demaree, 1932; Sharitz et al., 1974a; Harms et al., 1980). Increased flow rates in the tributary also resulted in the scouring of stream banks upstream from the delta. Eroded sediments were deposited in the delta, increasing siltation rates and contributing to tree kill (Sharitz et al., 1974a).

Restoration of a forest similar to predisturbance conditions in Pen branch is unlikely given the lack of desirable species in the understory (Muzika et al., 1987) or may take an extremely long time (De Steven and Sharitz, 1997). The reestablishment of water tupelo, swamp blackgum (Nyssa sylvatica var. biflora (Walt.) Sarg.), baldcypress, and other flood tolerant species is also limited by inappropriate environmental conditions and seed dispersal problems (Sherrod et al.,
1980). The rapid colonization by herbaceous species in the delta, along with black willow and buttonbush, may also be preventing the reestablishment of seedlings (Sharitz et al., 1974b; Sherrod et al., 1980; Gunderson, 1984; Kolka et al., 1998).

Another reason for the limited re-establishment of flood tolerant species on the delta is limited seed availability. The seed pool is small because few, if any parent trees remain to disperse seeds downstream (Sherrod et al., 1980; Sharitz and Lee, 1985; Dunn and Sharitz, 1987). Upstream locations which were more strongly affected by thermal effluents had higher tree mortality, effectively removing mature trees which could act as a seed source (McLeod and Sherrod, 1981). Additionally, baldcypress seed collected from the Savannah river site have low viability, usually below 10\% (McLeod and Sherrod, 1981).

Hydrology is not only important for seed dispersal (Schneider and Sharitz, 1988), but also affects seedling establishment and growth. The construction of upstream dams on the Savannah river is responsible for changes in the natural flooding pattern of the Pen branch delta (Sharitz and Lee, 1985; Sharitz et al., 1990). The natural pattern of winter flooding followed by low flow during the growing season gives seeds a chance to germinate. Although they are dispersed by water, baldcypress seeds require aerobic conditions for germination and will not germinate when submerged in water (Mattoon, 1916). Once established, seedlings must exhibit rapid initial height growth to prevent submergence during the next flood season (Demaree, 1932). The lack of open, moist microsites that would provide a chance for seed germination and allow seedling growth without the threat of overtopping flood waters may be attributed to anthropogenically-altered hydrology of the Savannah river (Sharitz and Lee, 1985; Huenneke and Sharitz, 1990). To promote regeneration of certain water logging tolerant hardwoods, hydrologic events which are artificially controlled should be synchronous with natural drawdown and flooding events (Sharitz and Lee, 1985; Sharitz et al., 1990).

Without natural seed sources and seasonal flood events, recovery to former conditions may 
take many years without intervention. Thus, planting of seedlings will hasten recovery of this area. Planting strategies, which may improve seedling growth and survival, as well as simplify the actual process of planting, are moderate pruning of the roots of desirable species to ease planting in the mucky substrate and the use of tree shelters for increased early height growth and protection from herbivory. The overall objective of this study was to compare the survival and growth over a 5-year period of four forested wetland species planted with and without tree shelters.

\section{Materials and methods}

Pen branch delta is located on the Savannah river site (SRS) near Aiken, SC and is fed by Pen branch creek which enters the swamp about $5 \mathrm{~km}$ from the river and flows southeastward (Fig. 1). The delta is characterized by shallow $(0-50 \mathrm{~cm})$ moving water which covers the experimental area year-round (De Steven and Sharitz, 1997).

Within the Pen branch delta experimental site, four different areas were defined: cleared, grass, willow, and muck. All vegetation in the cleared area was removed using a weed eater in late January 1994, while the grass area was left alone. The willow area consisted of an impinging canopy of willow (Salix spp.) species. The muck area was characterized by less grass competition and deeper surface water than the other plots. All seedlings in the four areas were subject to standing water conditions and some competition with surrounding herbaceous vegetation.

Two $12 \times 12-\mathrm{m}$ blocks were established in each of the four areas. Each block consisted of four species subplots, which contained five different treatments. The seedlings were planted on a $0.6 \times$ $0.6 \mathrm{~m}$ spacing during March 1994 with 100 seedlings per subplot ( 20 per treatment), totaling 400 seedlings per block or 3200 seedlings total. Species planted included baldcypress, water tupelo, green ash (Fraxinus pennsylvanica Marsh.), and swamp blackgum. These species were chosen because of their waterlogging tolerance (Hook, 1984) and their desirability as a source for regen- eration of the delta to closely resemble predisturbance ecology. Treatments included pruned roots, non-pruned roots, tree shelters $(1.5 \mathrm{~m}$ tall), and non-tree shelters. A fifth set of seedlings was planted to study alcohol dehydrogenase (ADH) levels in root tips. Only results from the tree shelter versus non-tree shelter experiment will be reported here since the results of the root pruning experiment were described in Funderburke and Conner (1997) while the ADH study was reported by Rozelle (1997).

Heights of all trees were taken after planting and height and survival data were taken at the end of each growing season from 1994 to 1998. Trees were counted as living as long as some portion of the stem was alive. Heights were measured to the top of the living stem. During survival assessments, herbivory was recorded where possible. Treatment means for height growth and survival was compared using analysis of variance. Where significant differences occurred, Fisher's protected LSD was used to determine which treatments or species differed. Data were analyzed using STATVIEW statistical software for the Macintosh (Abacus Concepts, 1989). An alpha level of 0.05 was used to determine significance.

Amount and type of competing vegetation in each area were collected in the growing season (August 1994) in a biomass survey. Eight randomly selected $0.25 \mathrm{~m}^{2}$ plots in each block were clipped and the vegetation identified, dried at $80^{\circ} \mathrm{C}$ for $48 \mathrm{~h}$, and weighed. Willow stems were counted in the willow blocks to estimate the density of the canopy species. Significant differences between biomass in the areas were determined using an unpaired $t$-test.

\section{Results}

Survival at the end of 5 years ranged from 67 to $100 \%$ for seedlings in tree shelters and $2-90 \%$ for those not in tree shelters (Table 1). Baldcypress and water tupelo survival was highest within tree shelters followed by green ash and swamp blackgum. Survival of seedlings without tree shelters was low, and mortality was attributed mainly to beaver damage. Many of the baldcypress and 
water tupelo stumps or clipped stems were still present at the time of measurement. In addition, $85 \%$ of the clipped baldcypress resprouted after clipping (some were clipped more than 1 year). The greatest amount of herbivory of baldcypress $(75 \%)$ occurred in the cleared plots, which happened to be the closest to an existing beaver lodge. The least herbivory $(7 \%)$ of baldcypress occurred in the muck plots which were the furthest from the beaver lodge. Similar amounts of predation $(45-47 \%)$ were observed in the grass and willow plots. It was much more difficult to determine the exact cause of death of the swamp blackgum and green ash seedlings, as no sign of the seedling stems or stumps could be found at the time of measurement.

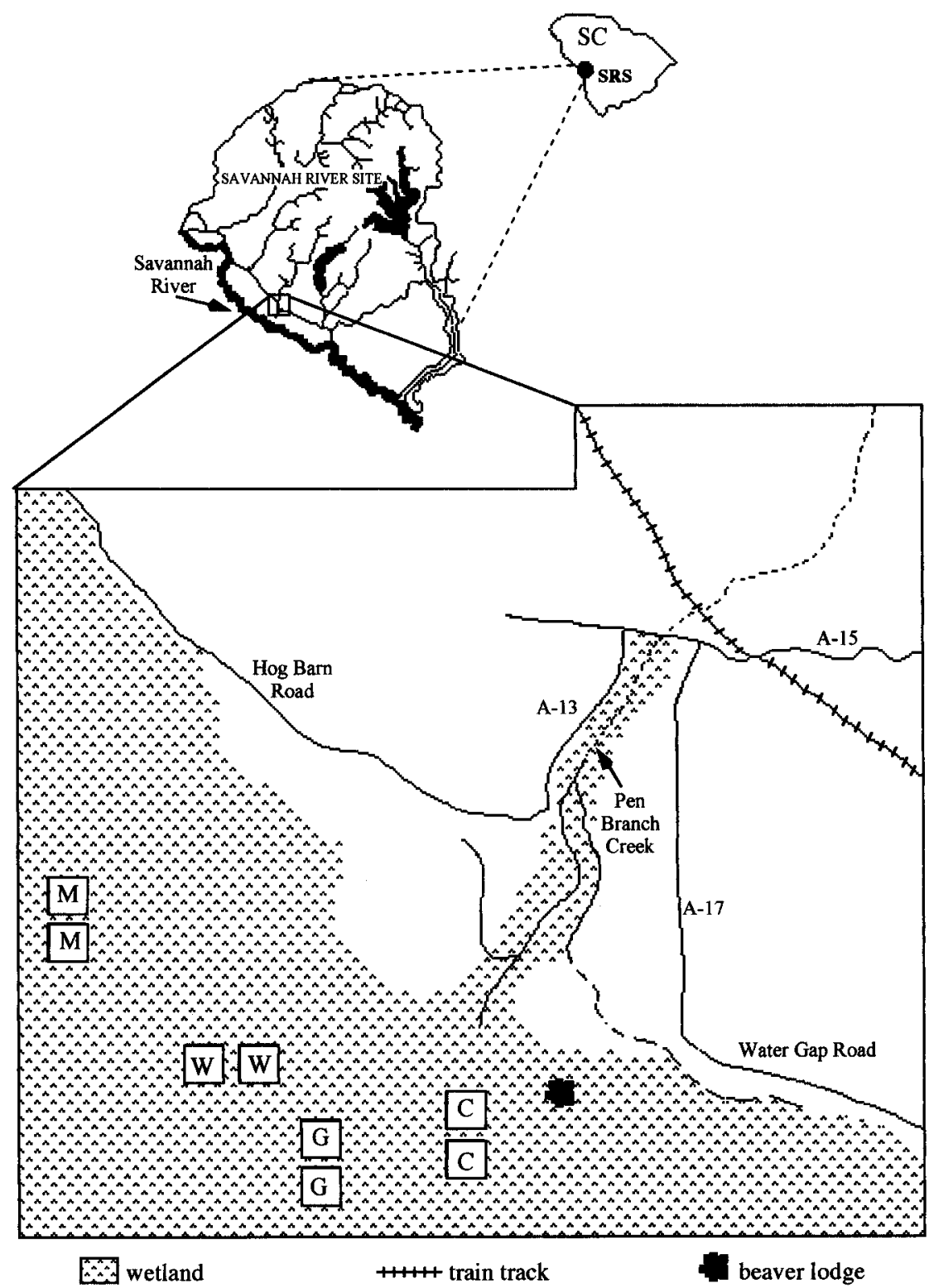

Fig. 1. Map showing the location of the study area within the Savannah river site. C, cleared; G, grass; W, willow and M, muck. 
Table 1

Percent survival at the end of 5 years for four species planted in the Pen branch delta with and without tree shelters ${ }^{\mathrm{a}}$

\begin{tabular}{|c|c|c|c|c|}
\hline \multirow[t]{2}{*}{ Method/species } & \multicolumn{4}{|l|}{ Area } \\
\hline & Cleared & Grass & Willow & Muck \\
\hline \multicolumn{5}{|l|}{ Baldcypress } \\
\hline Tree shelter & $97(3) \mathrm{a}$ & $100(0) \mathrm{a}$ & $97(2.5) \mathrm{a}$ & $100(0) \mathrm{a}$ \\
\hline Non-tree shelter & $88(7.5) \mathrm{a}$ & $90(0) \mathrm{b}$ & $45(10) b$ & $62(17.5) \mathrm{a}$ \\
\hline Tree shelter & $90(10) a$ & $98(2.5) \mathrm{a}$ & $98(2.5) \mathrm{a}$ & $98(2.5) \mathrm{a}$ \\
\hline Non-tree shelter & $30(5) \mathrm{b}$ & $5(5) \mathrm{b}$ & $5(5) \mathrm{b}$ & $40(0) \mathrm{b}$ \\
\hline \multicolumn{5}{|l|}{ Swamp blackgum } \\
\hline Tree shelter & $78(21.5) \mathrm{a}$ & $88(7.5) \mathrm{a}$ & $68(17.5) \mathrm{a}$ & $98(2.5) \mathrm{a}$ \\
\hline Non-tree shelter & $10(10) \mathrm{a}$ & $18(2.5) \mathrm{b}$ & $20(10) \mathrm{a}$ & $12(2.5) \mathrm{b}$ \\
\hline
\end{tabular}

a Value in parentheses is \pm 1 S.E. Unlike letters for each species within an area indicate a significant difference in survival rates between the tree shelter and non-tree shelter treatments $(\alpha=0.05)$.

Due to the effect of herbivory and the difficulty of determining if a cut stem was alive or not, seedlings clipped by animals were not included in height growth analyses. During year 1, height growth of tree shelter seedlings was significantly greater than non-tree shelter seedlings for all species (Fig. 2). Beginning in year 2, there was no longer a significant difference between tree shelter and non-tree shelter seedling growth for swamp blackgum and green ash except in 1997 for swamp blackgum. Height growth of baldcypress and water tupelo seedlings in tree shelters remained significantly greater in year 2 , but declined after that. During year 5, baldcypress height growth of nontree shelter seedlings was significantly greater than those in tree shelters. Even though height growth declined once seedlings emerged from the tree shelters, total height of seedlings with shelters has remained greater than seedlings without shelters (Fig. 3).

Differences in height growth among areas was highly variable from year to year (Table 2), and no one species tended to grow better in one area over another throughout the period. For example, tree shelter baldcypress height growth in the grass and muck areas was significantly greater than in the willow area in year 1 . In year 2 , height growth in the cleared area was significantly greater than growth in the willow area. By year 3, height growth in the willow area was significantly greater than that in the other three areas. Height growth in year 4 was greatest in the cleared area, but during year 5 , height growth was greatest in the grass and willow areas. Similar variability existed for the other species, both for tree shelter and non-tree shelter seedlings.

In 1994, seven plant species were identified as competing vegetation. These were bulrush (Scirpus cyperinus (L.) Kunth), false nettle (Boehmeria cylindrica (L.) Swartz), knotweed (Polygonum spp.), water-primrose (Ludwigia spp.), panic grass (Panicum spp.), rush (Juncus spp.), and cattail (Typha spp.). Although it depended on the area as to which genus was the most abundant, bulrush was usually the major component of the biomass samples. Panic grass appeared most often in the samples even if it was only a small portion of the total sample weight. There were no significant differences in herbaceous biomass in the cleared, grass, and muck plots $\left(200-350 \mathrm{~g} / \mathrm{m}^{2}\right)$, but herbaceous biomass was significantly less in the willow area $\left(70 \mathrm{~g} / \mathrm{m}^{2}\right)$. The willow area did contain $53 \pm 7$ tree stems per plot (canopy height of $6 \mathrm{~m}$ and maximum diameter of $10 \mathrm{~cm}$ ). By year 5 , the delta 
marsh was dominated by cattail and cut grass (Leersia oryzoides (L.) Swartz), which formed a 1.5-2.0 $\mathrm{m}$ tall layer nearly covering all of the planted areas except for the willow plots. The willow stands were beginning to break up by year 5.

\section{Discussion}

Restoring the Pen branch delta to a forested wetland is possible using flood tolerant species and some form of herbivory control. Tree shelters generally increased the chances of survival of all four species in this study, although there is some question as to the continued survival of the swamp blackgum and green ash seedlings. Other studies have shown that tree shelters increase
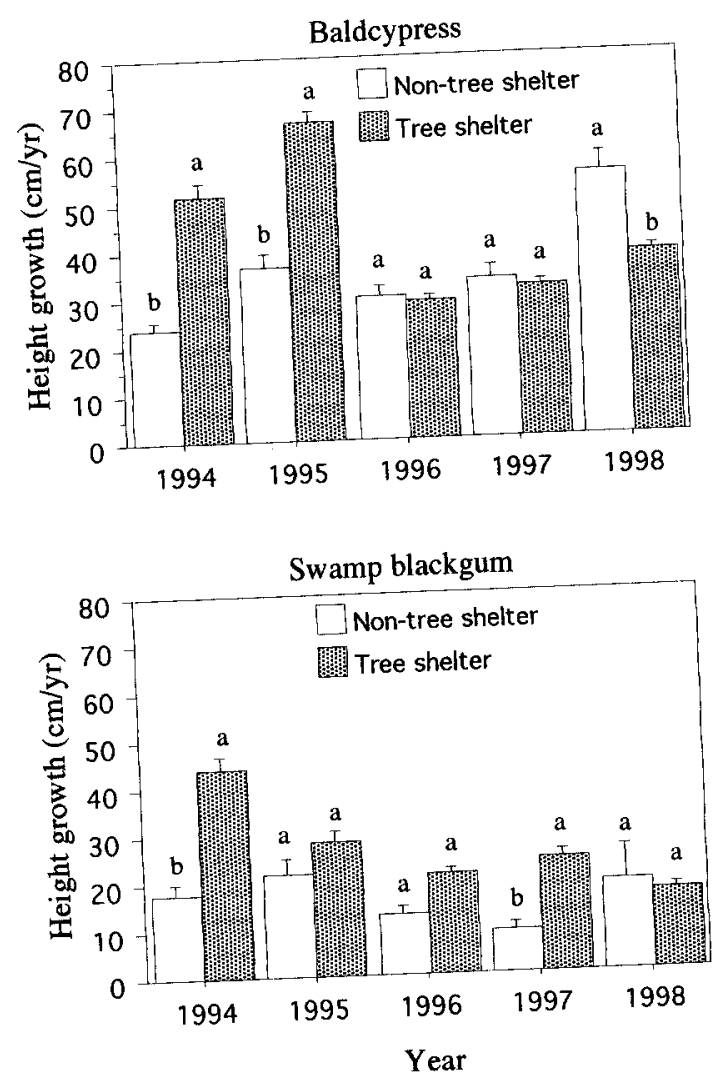

survival of seedlings in a variety of situations (Kittredge et al., 1992; Conkle, 1994; Mayhead and Boothman, 1997; Stange and Shea, 1998). In contrast, there has been at least one study reporting that tree shelters do not affect the survival of planted seedlings (Minter et al., 1992).

Even though a majority of the swamp blackgum and green ash seedlings within the tree shelters were considered to be alive at the end of 5 years, they did not appear to be very healthy. Many of them had dead or dying tops and resprouting had occurred lower on the stem. Rozelle (1997) noted in the first 2 years of the study that the green ash seedlings exhibited a declining root system, indicating that the species was not well suited for the almost constant flooding experienced within the planted areas. It is common for plants to exhibit root die-back upon
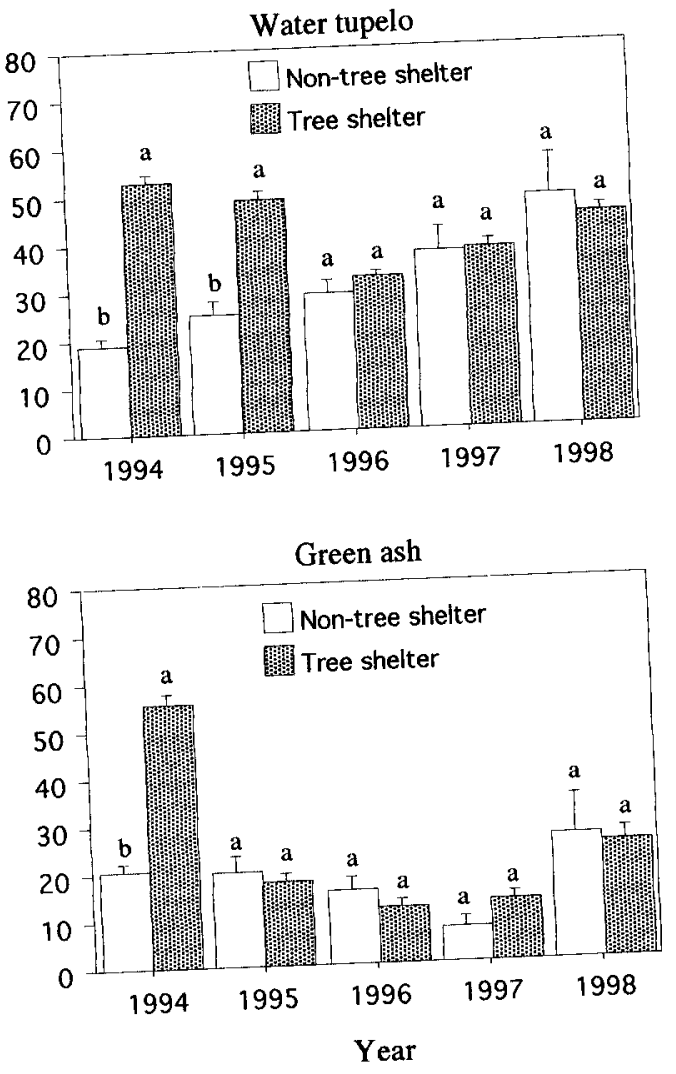

Fig. 2. Comparison of height growth ( \pm 1 S.E.) between tree shelter and non-tree shelter seedlings by year. Unlike letters represent statistical differences for the year at the $5 \%$ level. 

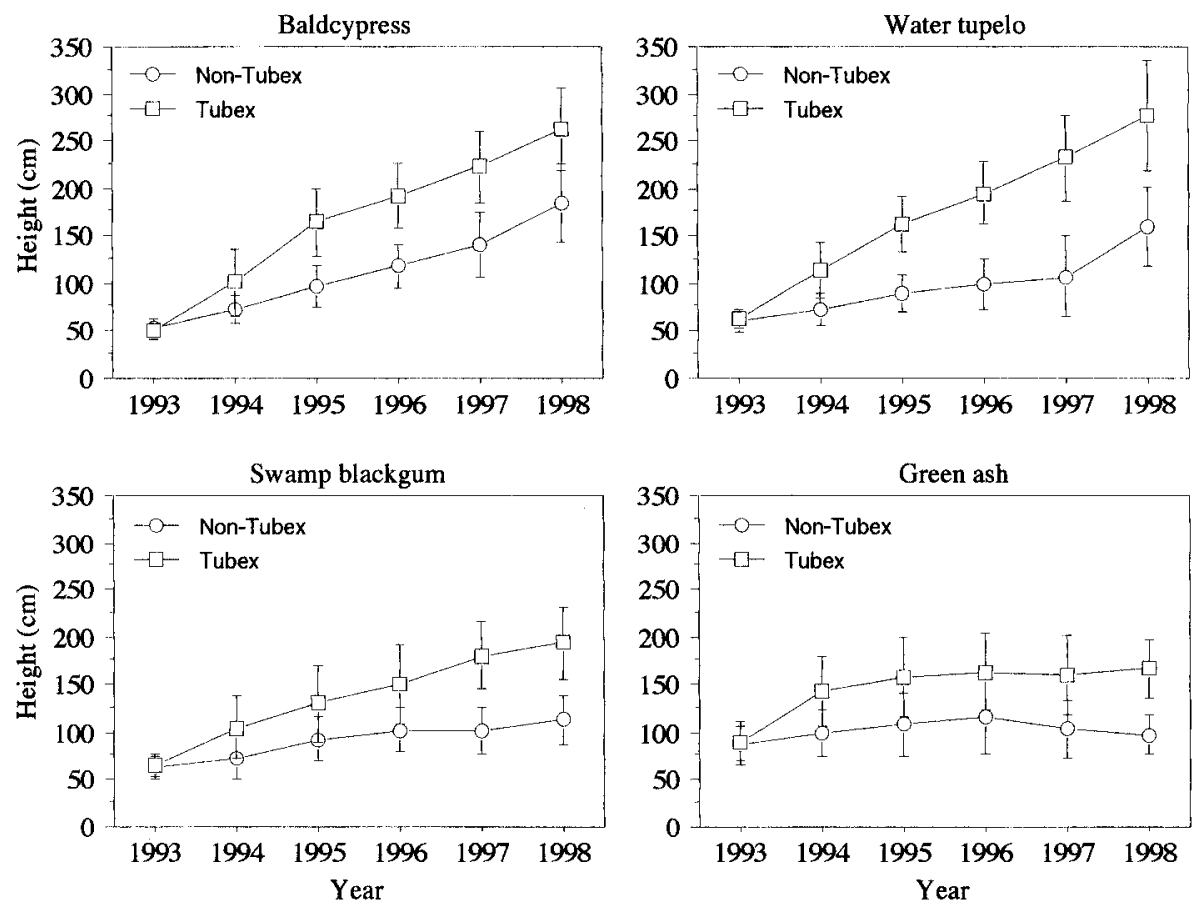

Fig. 3. Height ( \pm 1 S.D.) of seedlings of four species planted with and without tree shelters in the Pen branch delta. The 1993 measurement indicates the height of the seedlings at the time of planting. Subsequent measurements were taken at the end of each year.

flooding and later form more succulent water roots (Hook et al., 1970; Coutts and Nicoll, 1990). In this case, the green ash seedlings did not produce a healthy root system over time. Other studies have also shown that green ash does not do well when planted in water 30-60 cm deep (McLeod et al., 1996; McLeod, 2000). In drier areas of the Pen branch corridor, green ash survived and grew well (Dulohery et al., 2000).

Even though swamp blackgum is ranked as very tolerant to waterlogging (Hook, 1984), it is generally found in shallow swamps and along the edge of deep swamps. Hook (1984) also reports that swamp blackgum shows variation in flood tolerance in relation to flooding frequency of its parent population. This may have been a reason for the poor growth and survival exhibited by the seedlings planted in this study and in other studies on SRS (McLeod, 2000). We predict that the swamp blackgum and green ash seedlings will not survive much longer in the delta.

The use of tree shelters significantly increased early height growth of seedlings in this study. Previous studies (Lantagne et al., 1990; Kittredge et al., 1992; Lantagne, 1992; Minter et al., 1992; Conkle, 1994) have shown that this is probably the result of reduced browsing and increased growth response from microclimate differences inside the shelters as compared to outside (increased carbon dioxide levels, increased relative humidity, decreased transpiration loss, etc. all contributing to a greenhouse effect). Once the baldcypress, water tupelo, and green ash seedlings emerged from the top of the shelter, a decline in height growth occurred. Emergence occurred in year 1 for the green ash and in year 2 for the baldcypress and water tupelo. Mayhead and Boothman (1997) observed a similar response in a study with sessile oak (Quercus petrea). 


\section{Conclusions}

Overall, we are optimistic that restoration of the Pen branch delta to a baldcypress-water tupelo forest similar to the surrounding forest is possible. Baldcypress and water tupelo seem ideally suited to growing in all areas of the delta equally well. Although it is expensive to protect each seedling with a tree shelter, the survival rate was excellent in this study, and they increased early growth rates, helping to get the tops of the seedlings above the competing grass layer. Without tree shelters there is some indication that baldcypress may still be able to survive and grow. Baldcypress seedlings clipped by beaver exhibited a tendency to resprout lower on the stem, and the new shoots often grew faster than non-clipped shoots. If beaver populations are kept in control, enough baldcypress may survive to be able to produce an adequate stand of trees. It is difficult at the present time, however, to determine if restoration of the delta has been successful. It will take $10-20$ years before the seedlings are of sufficient size to not be affected by herbivory and old enough to produce sufficient quantities of seed to maintain the forest.

Table 2

Five-year height growth $(\mathrm{cm})$ of seedlings of four species of trees planted on the Pen branch delta with and without tree shelters a

\begin{tabular}{|c|c|c|c|c|c|c|c|c|}
\hline \multirow[t]{3}{*}{ Species/year } & \multicolumn{8}{|l|}{ Treatment } \\
\hline & \multicolumn{4}{|l|}{ Tree shelter } & \multicolumn{4}{|c|}{ Non-tree shelter } \\
\hline & $\mathrm{C}$ & $\mathrm{G}$ & W & $\mathbf{M}$ & $\mathrm{C}$ & $\mathrm{G}$ & W & $\mathbf{M}$ \\
\hline \multicolumn{9}{|l|}{ Baldcypress } \\
\hline 1994 & $49.2(5.8) \mathrm{ab}$ & $57.6(5.8) \mathrm{a}$ & $41.8(4.2) \mathrm{b}$ & $57.9(4.3) \mathrm{a}$ & $28.2(6.4) \mathrm{ac}$ & $16.0(2.1) \mathrm{b}$ & $29.5(2.7) \mathrm{a}$ & $19.5(1.9) b c$ \\
\hline 1995 & $78.2(6.1) \mathrm{a}$ & $64.7(4.8) \mathrm{ab}$ & $60.1(4.3) \mathrm{b}$ & $64.5(4.6) \mathrm{ab}$ & $44.3(6.1) \mathrm{a}$ & $45.0(6.5) \mathrm{a}$ & $29.0(2.6) \mathrm{b}$ & $26.4(3.0) \mathrm{b}$ \\
\hline 1996 & $25.8(2.7) \mathrm{b}$ & $25.0(2.0) \mathrm{b}$ & $38.5(3.0) \mathrm{a}$ & $25.6(2.80) \mathrm{b}$ & $31.4(2.3) \mathrm{a}$ & $35.1(5.3) \mathrm{a}$ & $30.4(4.3) \mathrm{ab}$ & $19.5(3.0) \mathrm{b}$ \\
\hline 1997 & $41.2(3.7) \mathrm{a}$ & $26.6(1.9) \mathrm{b}$ & $32.7(2.2) \mathrm{b}$ & $26.5(1.9) \mathrm{b}$ & $31.7(3.2) \mathrm{a}$ & $34.0(3.7) \mathrm{a}$ & $32.0(9.0) \mathrm{a}$ & $36.6(8.3) \mathrm{a}$ \\
\hline 1998 & $33.1(2.8) b$ & $41.9(2.7) \mathrm{a}$ & $42.0(2.8) \mathrm{a}$ & $35.5(2.4) \mathrm{ab}$ & $36.1(7.0) \mathrm{b}$ & $63.1(7.4) \mathrm{a}$ & $82.2(11.8) \mathrm{a}$ & $44.9(3.1) \mathrm{b}$ \\
\hline \multicolumn{9}{|l|}{ Water tupelo } \\
\hline 1994 & $46.1(3.5) \mathrm{b}$ & $48.0(3.8) \mathrm{b}$ & $59.9(4.9) \mathrm{a}$ & $55.7(3.6) \mathrm{a}$ & $26.6(3.6) \mathrm{a}$ & $15.7(2.6) \mathrm{bc}$ & $20.8(3.1) \mathrm{ac}$ & $9.0(2.2) \mathrm{b}$ \\
\hline 1995 & $54.5(3.1) \mathrm{a}$ & $58.3(3.3) \mathrm{a}$ & $39.5(4.0) \mathrm{b}$ & $43.7(3.0) \mathrm{b}$ & $34.7(5.5) \mathrm{a}$ & $26.1(4.2) \mathrm{ab}$ & $10.7(8.9) \mathrm{b}$ & $15.0(3.0) \mathrm{b}$ \\
\hline 1996 & $26.9(2.1) \mathrm{c}$ & $33.1(2.4) \mathrm{b}$ & $40.6(2.2) \mathrm{a}$ & $27.5(1.7) \mathrm{b}$ & $31.3(3.3) \mathrm{ab}$ & $22.2(9.3) \mathrm{ab}$ & $13.5(1.5) \mathrm{b}$ & $41.3(10.8) \mathrm{a}$ \\
\hline 1997 & $30.7(1.9) \mathrm{b}$ & $42.7(3.7) \mathrm{a}$ & $43.0(3.3) \mathrm{a}$ & $34.2(2.0) \mathrm{b}$ & $36.1(4.2) \mathrm{a}$ & $35.0(11.3) \mathrm{a}$ & - & $44.7(13.0) \mathrm{a}$ \\
\hline 1998 & $35.8(2.8) \mathrm{b}$ & $47.5(3.1) \mathrm{a}$ & $46.5(3.3) \mathrm{a}$ & $47.4(2.7) \mathrm{a}$ & $14.3(5.5) \mathrm{a}$ & $11.0^{\mathrm{b}}$ & - & $60.9(8.2) b$ \\
\hline \multicolumn{9}{|c|}{ Swamp blackgum } \\
\hline 1994 & $43.5(6.1) \mathrm{ab}$ & $59.2(5.6) \mathrm{a}$ & $32.7(5.2) \mathrm{b}$ & $41.6(4.4) \mathrm{b}$ & $14.6(5.2) \mathrm{b}$ & $18.4(3.4) b$ & $26.8(3.1) \mathrm{a}$ & $7.4(2.5) \mathrm{b}$ \\
\hline 1995 & $41.3(5.4) \mathrm{a}$ & $36.7(4.1) \mathrm{a}$ & $15.5(3.4) \mathrm{b}$ & $23.4(3.2) b$ & $25.6(8.2) \mathrm{a}$ & $19.6(3.1) \mathrm{a}$ & $15.3(13.3) \mathrm{a}$ & $26.5(19.6) \mathrm{a}$ \\
\hline 1996 & $19.0(2.3) \mathrm{a}$ & $21.4(1.8) \mathrm{a}$ & $20.9(3.6) \mathrm{a}$ & $22.1(2.9) \mathrm{a}$ & $17.9(4.3) \mathrm{a}$ & $9.7(2.0) \mathrm{b}$ & $14.6(2.8) \mathrm{ab}$ & $8.0^{\mathrm{b}}$ \\
\hline 1997 & $26.3(3.3) \mathrm{ac}$ & $18.8(2.8) \mathrm{bc}$ & $27.9(4.0) \mathrm{a}$ & $27.7(1.8) \mathrm{ac}$ & $10.7(2.9) \mathrm{a}$ & $8.4(2.9) \mathrm{a}$ & $6.5(3.0) \mathrm{a}$ & $8.0(1.0) \mathrm{a}$ \\
\hline 1998 & $13.1(2.4) \mathrm{a}$ & $15.9(2.4) \mathrm{a}$ & $18.4(2.9) \mathrm{a}$ & $17.7(2.9) \mathrm{a}$ & $7.0^{\mathrm{b}}$ & - & $14.4(7.8) \mathrm{a}$ & $13.0(3.4) \mathrm{a}$ \\
\hline \multicolumn{9}{|l|}{ Green ash } \\
\hline 1994 & $57.8(5.9) \mathrm{a}$ & $61.3(5.0) \mathrm{a}$ & $51.2(5.5) \mathrm{a}$ & $51.6(4.5) \mathrm{a}$ & $32.6(6.6) \mathrm{a}$ & $16.1(2.7) b$ & $18.8(1.9) \mathrm{b}$ & $14.5(2.3) \mathrm{b}$ \\
\hline 1995 & $23.0(2.7) \mathrm{a}$ & $27.5(4.3) \mathrm{a}$ & $8.8(2.9) \mathrm{b}$ & $10.6(2.2) \mathrm{b}$ & $19.4(4.1) \mathrm{ab}$ & $31.8(7.7) \mathrm{a}$ & $3.8(0.9) \mathrm{b}$ & $8.4(2.0) \mathrm{b}$ \\
\hline 1996 & $13.7(3.3) \mathrm{a}$ & $14.1(2.7) \mathrm{a}$ & $5.7(0.8) b$ & $14.6(4.5) \mathrm{a}$ & $21.1(6.2) \mathrm{a}$ & $15.5(4.6) \mathrm{a}$ & $6.7(0.9) \mathrm{a}$ & $10.4(5.8) \mathrm{a}$ \\
\hline 1997 & $10.4(1.4) \mathrm{a}$ & $11.5(2.8) \mathrm{a}$ & $18.1(4.9) \mathrm{a}$ & $14.8(3.0) \mathrm{a}$ & $5.3(2.2) \mathrm{a}$ & $11.3(4.7) \mathrm{a}$ & - & - \\
\hline 1998 & $8.8(7.8) \mathrm{a}$ & $17.6(4.4) \mathrm{a}$ & $31.2(5.3) \mathrm{a}$ & $21.7(3.5) \mathrm{a}$ & $21.0^{\mathrm{b}}$ & - & - & $27.1(9.0)$ \\
\hline
\end{tabular}

${ }^{\text {a }} \mathrm{C}$, cleared; G, grass; W, willow and $\mathrm{M}$, muck. Unlike letters indicate statistical differences at $5 \%$ level among areas within treatments by year and species. Value in parentheses is \pm 1 S.E. Missing values indicate that all seedlings were dead or affected by herbivory and not used in height growth analyses.

${ }^{\mathrm{b}}$ Only one seedling left alive or not affected by herbivory. 


\section{A.cknowledgements}

Funding came from the USFS Center for Forested Wetlands Research, Charleston, SC. Special thanks to Bill McKee, Amy Rozelle, Linda Copeland, Martha McKevlin, Jeff Vernon, Stephan Williams, Jan Gay, Ron Moseley, and Dave Gartner for their assistance in the field and lab. Additional thanks go to B. Graeme Lockaby, Ken McLeod, and Randy Kolka for comments on the manuscript. Belle W. Baruch Forest Science Institute Contribution No. 99:03.

\section{References}

A.bacus Concepts, 1989. SuperANOVA Accessible General Linear Modeling. Abacus Concepts, Inc., Berkeley, CA, 1989, 322 pp.

Conkle, J., 1994. The effects of tree shelters and soil drainage class on the growth and survival of twelve heavy-seeded species. M.S. Thesis, Clemson University, Clemson, SC.

Coutts, M.P., Nicoll, B.C., 1990. Waterlogging tolerance of roots of Sitka spruce clones and of strands from Thelephora terrestris mycorrhizas. Can. J. For. Res. 20, 1894-1899.

De Steven, D., Sharitz, R.R., 1997. Differential recovery of a deepwater swamp forest across a gradient of disturbance intensity. Wetlands 17 (4), 476-484.

Demaree, D., 1932. Submerging experiments with Taxodium. Ecology 13, 258-262.

Donovan, L.A., McLeod, K.W., Sherrod, K.C. Jr, Stumpff, N.J., 1988. Response of wood swamp seedlings to flooding and increased water temperatures. I. Growth, biomass, and survivorship. Am. J. Bot. 75 (8), 1181-1190.

Dulohery, C.J., Kolka, R.K., McKevlin, M.R., 2000. Effects of a willow overstory on planted seedlings in a bottomland restoration. Ecol. Eng.

Dunn, C.P., Sharitz, R.R., 1987. Revegetation of a TaxodiumNyssa forested wetland following complete vegetation destruction. Vegetatio 72, 151-157.

Funderburke, E.L., Conner, W.H., 1997. Use of root pruning to facilitate planting of wetland species in a thermally impacted area. Tree Planters Notes 48, 76-80.

Gunderson, L.H., 1984. Regeneration of cypress in logged and burned strands at Corkscrew Swamp Sanctuary, Florida. In: Ewel, K.C., Odum, H.T. (Eds.), Cypress Swamps. University Press of Florida, Gainesville, FL, pp. 349-357.

Harms, W.R., Schreuder, H.T., Hook, D.D., Brown, C.L., Shropshire, F.W., 1980. The effects of flooding on the swamp forest in Lake Ocklawah, Florida. Ecology 61, 1412-1421.

Hook, D.D., 1984. Water tolerance of lowland tree species of the south. South J. Appl. For. 8, 136 149.
Hook, D.D., Langdon, O.G., Stubbs, J., Brown, C.L., 1970. Effect of water regimes on the survival, growth, and morphology of tupelo seedlings. For. Sci. 16, 304-311.

Huenneke, L.F., Sharitz, R.R., 1990. Substrate heterogeneity and regeneration of a swamp tree, Nyssa aquatica. Am. J. Bot. 77 (3), 413-419.

Kittredge, D.B. Jr, Kelty, M.J., Ashton, P.M.S., 1992. The use of tree shelters with northern red oak natural regeneration in southern New England. North J. Appl. For. 9, 141-145.

Kolka, R.K., Nelson, E.A., Bonar, R.E., Dulohery, N.C., Gartner, D., 1998. The Pen branch project: restoration of a forested wetland in South Carolina. Restor. Manage. Notes 16 (2), 149-157.

Lantagne, D.O., 1992. Tree shelters increase heights of planted northern red oaks. In: McCormick, L.H., Gottschalk, K.W. (Eds.), Eighth Central Hardwood Forest Conference. USDA Forest Service, Northeastern Forest Experiment Station, pp. $291-298$.

Lantagne, D.O., Ramm, C.W., Dickmann, D.I., 1990. Tree shelters increase heights of planted oaks in a Michigan clearcut. North J. Appl. For. 7, 24-26.

Mattoon, W.R., 1916. Water requirements and growth of young cypress. Proc. Soc. Am. For. 11, 192-197.

Mayhead, G.J., Boothman, I.R., 1997. The effect of treesheter height on the early growth of sessile oak (Quercus petraea (Matt.) Liebl.). Forestry 70 (2), 151-155.

McLeod, K.W., 2000. Species selection trial and silvicultural techniques for the restoration of bottomland forests. Ecol. Eng.

McLeod, K.W., Sherrod, C. Jr, 1981. Baldcypress seedling growth in thermally altered habitats. Am. J. Bot. 68, 918-923.

McLeod, K.W., Donovan, L.A., Stumpff, N.J., 1987. Responses of woody seedlings to elevated floor water temperatures. In: Hook, D.D., McKee, W.H. Jr, Smith, H.K., Gregory, J., Burrell, V.G. Jr, DeVoe, M.R., Sojka, R.E., Gilbert, S., Banks, R., Stolzy, L.H., Brooks, C., Matthews, T.D., Shear, T.H. (Eds.), The Ecology and Management of Wetlands. Timber Press, Portland, pp. 441-451.

McLeod, K.W., Reed, M.R., Ciravolo, T.G., 1996. Reforesting a damaged stream delta. Land Water 40 (4), 11-13.

Minter, W.F., Meyers, R.K., Fischer, B.C., 1992. Effects of tree shelters on northern red oak seedlings planted in harvested forest openings. North J. Appl. For. 9, 58-63.

Muzika, R.M., Gladden, J.B., Haddock, J.D., 1987. Structural and functional aspect of succession in southeastern floodplain forests following a major disturbance. Am. Midl. Nat. 117, 10-16.

Rozelle, A., 1997. Use of morphological and physiological traits to assess seedling response to flooding stress of four wetland tree species. M.S. Thesis, Clemson University, Clemson, SC.

Schneider, R.L., Sharitz, R.R., 1988. Hydrochory and regeneration in a bald cypress-water tupelo swamp forest. Ecology 69, 1055-1063.

Scott, M.L., Sharitz, R.R., Lee, L.C., 1985. Disturbance in a cypress-tupelo wetland: an interaction between thermal loading and hydrology. Wetlands 5, 53-68. 
Sharitz, R.R., Lee, L.C., 1985. Limits on regeneration processes in southeastern riverine wetlands. In: Riparian Ecosystems and Their Management: Reconciling Conflicting Uses, General Technical Report RM-120, USDA, Ft. Collins, CO, pp. $139-160$.

Sharitz, R.R., Mitsch, W.J., 1993. Southern floodplain forests. In: Martin, W.H., Boyce, S.G., Esternacht, A.C. (Eds.), Biodiversity of the Southeastern United States: Lowland Terrestrial Communities. Wiley, New York, NY, pp. 311372.

Sharitz, R.R., Gibbons, J.W., Gause, S.C., 1974a. Impact of production-reactor effluents on vegetation in a southeastern swamp forest. In: Gibbons, J.W., Sharitz, R.R. (Eds.), Thermal Ecology, AEC Symposium Series (Conf-730505), pp. $356-362$.

Sharitz, R.R., Irwin, J.E., Christy, E.J., 1974b. Vegetation of swamps receiving reactor effluents. Oikos 25, 7-13.
Sharitz, R.R., Schneider, R.L., Lee, L.C., 1990. Composition and regeneration of a disturbed river floodplain forest in South Carolina. In: Gosselink, J.G., Lee, L.C., Muir, T.A. (Eds.), Ecological Processes and Cumulative Impacts: Illustrated by Bottomland Hardwood Wetland Ecosystems. Lewis Publishers, Chelsea, MI, pp. 195-218.

Sherrod, C. Jr, Somers, D.E., McLeod, K.W., 1980. Potential for baldcypress establishment in thermally altered streams. J. Thermal Biol. 5, 107-111.

Stange, E.E., Shea, K.L., 1998. Effects of deer browsing, fabric mats, and tree shelters on Quercus rubra seedlings. Restor. Ecol. 6 (1), 29-34.

Wike, L.D., Shipley, R.W., Bowers, J.A., Bryan, A.L., Cummins, C.L., del Carmen, B.R., Friday, G.P., Irwin, J.E., Mackey Jr., H.E., Mayer, J.J., Nelson, E.A., Paller, M.H., Rogers V.A., Specht, W.L., Wilde, E.L., 1994. SRS ecology: environmental information document. Westinghouse Savannah River Company, Aiken, SC, WSRC-TR-93-496. 